\title{
Variability in Selected Soil Properties of Soils of Dissimilar Parent Materials in the Humid Tropics
}

\author{
Nkwopara U.N.
}

\author{
Department of Soil Science, Federal University of Technology, Owerri. P.M.B 1526, Imo State, Nigeria. \\ Correspondening Author: ugoiken2003@yahoo.com ,ugochukwu.nkwopara@futo.edu.ng
}

\begin{abstract}
The study investigated variability of selected soil properties of soils derived from different parent materials (that is false bedded sandstone and Imo clay shale) in the humid tropic. Soil samples were collected from horizons based on profile differentiation. Data collected were subjected to statistical analysis using coefficient of variation $(C V)$ and correlation. There were variations in soil properties of the two studied areas. Results showed that soil properties differed in their degree of variation among the parent materials. Sand content had little variation in both soils $(\mathrm{CV}=6.56 \%$ and $C V=17.23 \%)$ for false bedded sandstone and Imo clay shale respectively. Clay had moderate variation in both soils (CV $=40.17 \%$ and 36.50 $\%)$ for false bedded sand stone and Imo clay shale respectively. Bulk density and $\mathrm{pH}$ had little variation in both soils $C V=7.30 \%$ and $C V=4.29$ ) in false bedded sandstone while ( $C V=6.16 \%$ and $4.85 \%)$ in Imo clay shale. Organic matter varied highly in false bedded sandstone $(C V=51.32 \%)$ while in Imo clay shale it varied moderately $(C V=42.30 \%)$. Organic matter had positive significant relationship with clay content in both soils $(r$ $=0.98,0.99, P<0.05)$ for false bedded sandstone and Imo clay shale respectively. $\mathrm{pH}$ had a negative relationship with Available phosphorus in false bedded sandstone $(r=-0.45$, $P<0.05)$ while in Imo clay shale $p H$ had positive significant relationship with Available phosphorus ( $r$ 0.96, $P<0.05)$. pH had non- significant positive relationship with organic matter in both soils $(r=0.63$, 0.06, $p<0.05)$ for false bedded sandstone and Imo clay shale respectively. A more intensive soil sampling from the study area with the inclusion of more parameters will provide a better and reliable representation of the variability of soil properties even at a regional scale.
\end{abstract}

Keywords - variability, Pedon, Parent material, Tropical soils.

\section{INTRODUCTION}

Most soil users in South-eastern Nigeria have regarded the soils to be the same in every respect simply because they are all in the same geographical location. Information on variation in soil properties enable potential soil users to appreciate the behavior of the various types of soils in the region, so that they can be utilized appropriately to derive optimum productivity [3]. Soils exhibit tremendous variability in their biological, chemical and physical properties [20]. According to [18] variation in soil properties has long been known and has been the subject of much research.

Pedologists have identified fundamental soil forming processes that influence soil properties: parent material, topography, climate, time and organisms [28]. Parent materials affect the morphological and physico-chemical characteristics of the soils under the same agro-ecological condition [14][13]. However, living organisms such as vegetation also have an important role in a number of processes involved in soil formation including organic matter accumulation, profile mixing and biogeochemical nutrient cycling [20]

[25] working on Alfisols of Southwestern Nigeria observed that soil $\mathrm{pH}$ was the least variable ( low variability) property, irrespective of depth. The variability of soil properties like organic matter, available phosphorus, total nitrogen and Cation Exchange Capacity, increases with depth. Properties such as $\mathrm{pH}$ and porosity are among the least variables, while those pertaining to water or solute transport are among the most variable.

Soils of South-eastern Nigeria are formed from diverse parent materials [26]. Information on how these parent materials and their corresponding pedogenic processes influence soil properties in South-eastern Nigeria is limited. [20] reported on the variability in soil properties in relation to topography. Based on the above, we investigated the variation in properties of soils derived from two different parent materials in South-eastern Nigeria.

\section{Materials and Methods}

\subsection{Study area}


The study was conducted in two different locations namely Amuro (Okigwe LGA), which has Imo clay shale as its parent material located between latitude $5^{\circ} 48^{\prime} \mathrm{N}$ and longitude $7^{\circ} 20^{\prime} \mathrm{E}$ and Mbiakpa Ibakesi (Ini LGA) which has false bedded sandstone as its parent material located between latitude $5^{\circ} 25^{\prime} \mathrm{N}$ and longitude $7^{\circ} 44^{\prime} \mathrm{E}$. The two study locations are in Imo State which lies between latitude $4^{\circ} 40^{\prime} \mathrm{N}$ and longitude $6^{\circ} 40^{\prime} \mathrm{E}$ and Akwa Ibom State which lies between latitude $5^{\circ} 03^{\prime} \mathrm{N}$ and longitude $7^{\circ}$ 93' $\mathrm{E}$, both in Southern Nigeria Imo state lies within the humid tropics. Temperatures are high and change slightly during the year (mean daily temperature about $27^{\circ} \mathrm{C}$ ) [21]. The average annual rainfall is about $2400 \mathrm{~mm}$ and there is a distinct dry season of about 3-month dryness. Imo State has rainforest vegetation characterized by multiple tree species [26]. Agriculture is a major socio-economic activity in the study area. Agricultural crops mostly cultivated in the study area include yam (Dioscorea Spp), cassava (Manihot Spp), oil palm (Elaies guineensis) and maize (Zea mays). Akwa Ibom State also lies within the humid tropics with temperature of $27^{\circ} \mathrm{C}$ to $31^{\circ} \mathrm{C}$. Average annual rainfall is about $2500 \mathrm{~mm}$ to $3000 \mathrm{~mm}$. Relative humidity of Akwa Ibom state is about $75 \%-80 \%$ [11].

\subsection{Field study}

Prior to field study, a reconnais sance visit was made at each of the study locations in the early 2016; and this was followed by field sampling. Sampling sites were selected using free survey sampling techniques. One profile pit was dug at each of the various sampling site, summing to a total of two profile pits dug for the study. The study sites and profile pits were geo-referenced with the aid of a hand held Global Positioning System (GPS) receiver. The profile pits were described using [10] guidelines. Delineation of horizon boundaries was accomplished before actual sample collection for laboratory analyses and samples were collected according to horizons. A total of 30 soil samples were collected for the study. The soil samples were airdried, crushed, sieved through $2 \mathrm{~mm}$ sized sieve mesh. Ten grams (10 g) of each sample was finely grounded and preserved for determination of organic carbon and total nitrogen. Undisturbed soil samples for determination of bulk density were collected using core sampler.

\subsection{Laboratory analysis}

The particle size analysis was determined using the hydrometer method [12]. 5\% calgon (sodium hexametaphosphate) solution was used vas dispersing agent. Gravimetric Moisture Content was determined by gravimetric method. This method involves weighing representative soil samples into moisture cans. Samples were oven dried and weight also obtained. Moisture calculated using formula

www.ijeab.com
$\theta=\mathrm{Mw} / \mathrm{M}$

$\therefore \mathrm{Mc}=\mathrm{Mw} / \mathrm{Ms} \mathrm{X} 100 / 1$

Where $\theta=$ gravimetric moisture content, $\mathrm{Mt}=$ total soil mass, $\mathrm{Mw}=$ mass of water, $\mathrm{Ms}=$ mas $\mathrm{s}$ of solid particles.

Bulk density were taken in-situ using core samplers. The samples collected were oven dried after which bulk density calculated using the formula

$$
\begin{gathered}
\text { Bulk density }\{\mathrm{pB}\}=\underline{\text { mass of dry soil }}= \\
\text { Volume of soil core sampler }
\end{gathered}
$$

Bulk volume of soil $=$ volume of cylinder $=\left(\pi r^{2} h\right)$ Where $\mathrm{r}$ $=$ radius, $\mathrm{h}=$ height of cylinder.

Soil $\mathrm{pH}$ was determined using a soil $\mathrm{pH}$ meter and this was done in both distilled water and $0.1 \mathrm{~N} \mathrm{KCl}$ in a soil water ratio of 1:2:5. The $\mathrm{pH}$ of the resulting suspension was then read from a $\mathrm{pH}$ meter. Organic Carbon was determined by acid dichromate digestion and wet oxidation method [29]. Organic matter was obtained from organic carbon by multiplying by 1.724 . Total Nitrogen was determined by the regular Kjeldhal method [6].Available Phosphorus was determined using Bray 2 method [5].

Exchangeable bases ( $\mathrm{Ca}, \mathrm{Mg}, \mathrm{Na}$ and $\mathrm{K}$ ). Exchangeable $\mathrm{Na}$ and $\mathrm{K}$ was extracted using $1 \mathrm{~N} \mathrm{NH}_{4} \mathrm{OAC}$ using flame photometer [16].Exchangeable acidity was determined by extracting the soil with $0.1 \mathrm{~N} \mathrm{KCl}$ solution and titrating the aliquot of the extract with $1 \mathrm{~N} \mathrm{NaOH} \mathrm{[19].} \mathrm{Effective} \mathrm{cation}$ Exchange Capacity ( CEC) was determined by the summation of exchangeable cations $\left(\mathrm{Ca}^{2+}, \mathrm{Mg}^{2+}, \mathrm{K}^{+}, \mathrm{Na}^{+}\right)$ and exchangeable acidity $\left(\mathrm{H}^{+}\right.$and $\left.\mathrm{Al}^{3+}\right)$. The summation of the exchangeable bases and acidity gave the effective cation exchange capacity (ECEC) value.

\subsection{Statistical analysis}

The data was analyzed using the Coefficient of Variation (CV) procedure, ranking of variability according to [4]. The percentage $\mathrm{CV}$ values were graded as little variation (0$20 \%$ ) moderate variation $(20-50 \%)$ and high variation (50$100 \%)$. Correlation was used to determine the degree of relationship among soil properties of the different parent materials using SPSS. The experiment was replicated two times. Only the mean values are reported.

\section{RESULTS AND DISCUSSIONS}

\subsection{Physical properties of soil.}

The profile distributions of the physical properties of the soils are presented in Table 1. The distribution of clay down the profile showed moderate variation (cv 20-50\%) Table 1. This observation is in line with [25] who stated that $\%$ clay range from moderate to high variability. The distribution of total porosity down the profile showed little variation ( $\mathrm{cv}<20 \%$ ) (Table 1$)$. This observation is in line with [25] who stated that properties such as soil $\mathrm{pH}$ and porosity are among the least variables. The mean bulk 
density values $\left(0.73-1.55 \mathrm{gcm}^{-3}\right)$ recorded across the soils investigated were below the value quoted as the minimum bulk density at which root restricting conditions will occur $\left(1.75-1.80 \mathrm{Mgm}^{-3}\right)$ [27] showing that the soils were not compacted [2]. Generally in normal soil bulk density ranges from $1-1.60 \mathrm{gm} / \mathrm{cc}$ [7]. Generally, bulk density increased down the profile pit in all the soils. The results of coefficient of variation analysis showed little variation in the vertical distribution of the bulk density values (Table 1). This result is consistent with findings by [3] who observed little to moderate variation in the vertical distribution of bulk density in soil of contrasting lithosequence in Southeastern Nigeria. Moisture contents of the soils showed little variations $(\mathrm{cv}<20 \%)$ among the soils. This result is contrary to findings by [3] who observed high variation in the vertical distribution of moisture contents in soil of contrasting lithosequence in Southeastern Nigeria. With exception of the pedon developed on shale, the distribution of moisture contents in the profile pit increased with depth, indicating that the epipedon contains lesser quantity of moisture compared to the sub-surface horizons and could be a reflection of the clay contents of these horizons. Clay has high rate of adsorption and can retain water easily. Moisture content increased with increasing clay content as the clay would cause impaired drainage especially at the sub-surface horizons [23].

Table.1: physical properties of studied sites

\begin{tabular}{|c|c|c|c|c|c|c|c|c|}
\hline Site & Origin of soils & $\begin{array}{l}\text { Depth } \\
\text { (cm) }\end{array}$ & $\begin{array}{l}\text { Sand } \\
(\mathrm{g} / \mathrm{kg})\end{array}$ & $\begin{array}{l}\text { Silt } \\
(\mathrm{g} / \mathrm{kg})\end{array}$ & $\begin{array}{l}\text { Clay } \\
(\mathrm{g} / \mathrm{kg})\end{array}$ & $\begin{array}{l}\text { Bulk } \\
\text { density } \\
(\mathrm{g} / \mathrm{cm} 3)\end{array}$ & $\begin{array}{l}\text { Total } \\
\text { porosity } \\
(\%)\end{array}$ & $\mathrm{MC}(\%)$ \\
\hline Mbiakpa & Falsebedded & & & & & & & \\
\hline \multirow[t]{8}{*}{ Ibakesi } & sandstone & $0-20$ & 842.4 & 80 & 77.6 & 1.45 & 45.30 & 12.39 \\
\hline & & $20-35$ & 782.4 & 100 & 117.6 & 1.43 & 46.10 & 12.84 \\
\hline & & $35-69$ & 842.4 & 60 & 97.6 & 1.57 & 40.80 & 15.27 \\
\hline & & $69-108$ & 732.4 & 50 & 217.6 & 1.58 & 40.40 & 15.19 \\
\hline & & 108-192 & 722.4 & 60 & 217.6 & 1.71 & 35.50 & 12.95 \\
\hline & & mean & 784.4 & 70 & 145.6 & 1.55 & 41.62 & 13.73 \\
\hline & & STDV & 5.154 & 2 & 6.723 & 0.1132 & 4.28 & 1.40 \\
\hline & & $\mathbf{C V}$ & 6.57 & 28.57 & 40.17 & 7.30 & 10.28 & 10.10 \\
\hline \multirow[t]{9}{*}{ Amuro } & Imo clay shale & & & & & & & \\
\hline & & $0-15$ & 702.4 & 160 & 137.6 & 0.67 & 74.1 & 19.00 \\
\hline & & $15-25$ & 622.4 & 180 & 177.6 & 0.70 & 73.6 & 15.00 \\
\hline & & $25-50$ & 522.4 & 155.2 & 322.4 & 0.73 & 72.5 & 17.80 \\
\hline & & $50-69$ & 482.4 & 156.0 & 361.6 & 0.77 & 70.9 & 19.30 \\
\hline & & $69-150$ & 482.4 & 170 & 347.6 & 0.77 & 70.7 & 17.80 \\
\hline & & mean & 562.4 & 164.2 & 273.4 & 0.73 & 72.4 & 17.80 \\
\hline & & STDV & 9.70 & 1.06 & 9.98 & 0.04 & 1.487 & 1.70 \\
\hline & & CV & 17.23 & 6.45 & 36.50 & 6.05 & 2.10 & 20.5 \\
\hline
\end{tabular}

\subsection{Chemical properties}

The chemical properties of soil of the studied area are presented in Table 2. The $\mathrm{pH}$ values of the soils were moderately acidic with mean values ranging from 5.07 to 5.89. The acidic nature of the soils shows the inherent characteristics of soils of the study area irrespective of their parent materials. [1] [15] [3] reported similar findings in some soils of Southeastern Nigeria. The organic matter content of soils was low with a mean value ranging from 0.64 to $2.69 \%$. Organic matter decreased with depth in all the pedons (Table 2). The higher proportions of organic matter at the epipedon could be due to the fact that most of the organic residues are incorporated or deposited on the www.jieab.com soil surface. Top soil organic matter contents are directly related to organic carbon inputs and there have been a number of studies demonstrating improvements in soil quality and fertility after organic carbon additions [8]. The higher concentration of organic matter at epipedal horizons was further revealed by the moderate to high variation $(\mathrm{cv}>$ $35 \%$ ) observed in the organic matter contents of the varying horizons in all the pedons.

The nitrogen content of soils was low with the mean total nitrogen content in both soils being $0.01 \%$. However, the nitrogen contents of the surface horizons were higher than the sub-surface horizons and may be attributed to the organic matter contents of these horizons. The higher 
nitrogen at epipedal horizons was further revealed by the moderate to high variation ( $\mathrm{cv}>35 \%)$ observed in the nitrogen contents of the varying horizons in all the pedons. The Effective Cation Exchange Capacity (ECEC) of soils was generally low with the mean value ranging from 2.57 to $2.99 \mathrm{cmolkg}^{-1}$. Soils of South-eastern Nigeria had earlier been reported to be made of low ECEC and basic cations [24] [22].

Table.2: Chemical properties of studied sites

\begin{tabular}{|c|c|c|c|c|c|c|c|c|c|c|c|}
\hline $\begin{array}{l}\text { Origin of } \\
\text { soils }\end{array}$ & Horizon & $\mathrm{pH}(\mathrm{H} 20)$ & $\begin{array}{l}\mathrm{Om} \\
\mathrm{gkg}^{-1}\end{array}$ & $\begin{array}{l}\mathrm{TN} \\
\mathrm{g} / \mathrm{kg}^{-1}\end{array}$ & $\begin{array}{l}\text { Av. P } \\
\mathrm{mg} / \mathrm{kg}\end{array}$ & $\begin{array}{l}\text { TEB } \\
\left(\mathrm{cmolkg}^{-1}\right)\end{array}$ & $\begin{array}{l}\mathrm{Al} \\
\left(\mathrm{cmolkg}^{-1}\right)\end{array}$ & $\begin{array}{l}\text { EA } \\
(\mathrm{cmolk} \\
\left.\mathrm{g}^{-1}\right)\end{array}$ & $\begin{array}{l}\text { ECEC } \\
(\mathrm{cmol} \\
\left.\mathrm{kg}^{-1}\right)\end{array}$ & $\begin{array}{l}\mathrm{BS}(\% \\
)\end{array}$ & $\begin{array}{l}\text { A } 1 \\
\text { sat } \\
(\%)\end{array}$ \\
\hline
\end{tabular}

False

bedded

sandston

e

Imo clay

$\begin{array}{lllllllllll}\text { Ap } & 6.01 & 26.40 & 1.24 & 13.38 & 1.62 & - & 0.44 & 2.06 & 78.64 & - \\ \text { AB } & 5.60 & 24.70 & 1.18 & 3.15 & 1.05 & - & 0.46 & 1.15 & 69.53 & - \\ \text { Bt1 } & 5.61 & 23.60 & 0.80 & 10.85 & 2.03 & 1.04 & 0.41 & 3.48 & 58.33 & 29.88 \\ \text { Bt2 } & 5.43 & 9.80 & 0.88 & 18.83 & 1.87 & 1.01 & 0.35 & 3.23 & 57.89 & 31.32 \\ \text { Bt3 } & 5.41 & 6.40 & 0.69 & 11.76 & 1.43 & 1.03 & 0.46 & 2.91 & 48.79 & 35.34 \\ \text { mean } & 5.61 & 18.20 & 0.96 & 11.69 & 1.60 & 0.69 & 0.42 & 2.57 & 62.64 & 32.18 \\ \text { STDV } & 0.241 & 0.93 & 0.02 & 5.69 & 0.38 & 0.59 & 0.05 & 0.96 & 11.58 & 2.87 \\ \text { CV(\%) } & 4.39 & 51.33 & 25.00 & 48.50 & 24.00 & 85.80 & 0.85 & 37.20 & 18.49 & 8.92\end{array}$

shale

\begin{tabular}{lllllllllll} 
Ap & 6.50 & 26.90 & 1,20 & 7.42 & 2.14 & - & 1.40 & 3.54 & 60.45 & - \\
A & 6.60 & 23.00 & 1.08 & 2.52 & 1.14 & - & 1.00 & 2.14 & 58.51 & - \\
Bt1 & 6.11 & 14.80 & 0.86 & 0.35 & 0.92 & - & 3.40 & 4.32 & 21.29 & - \\
Bt2 & 6.05 & 11.00 & 0.50 & 2.66 & 1.33 & - & 1.20 & 2.53 & 52.57 & - \\
Bt3 & 5.90 & 10.70 & 0.44 & 2.54 & 1.14 & - & 1.00 & 2.14 & 52.27 & - \\
mean & 6.23 & 17.30 & 0.96 & 3.11 & 1.39 & - & 1.60 & 2.99 & 49.04 & - \\
STDV & 0.30 & 0.73 & 0.06 & 2.58 & 0.46 & - & 1.02 & 0.91 & 15.93 & - \\
CV (\%) & 4.85 & 42.30 & 58.33 & 82.96 & 33.17 & - & 63.75 & 30.57 & 32.48 & - \\
\hline
\end{tabular}

3.3 Relationship among selected physiochemical properties . The relationships among selected soil properties are shown in Table 3. The result shows that organic matter had a positive significant relationship with clay in all the soils suggesting that organic matter increase as clay content increases $(\mathrm{r}=0.97,0.99 \mathrm{P}<0.05)$.Soil $\mathrm{pH}$ had significant positive relationship with available $\mathrm{P}$ in Imo clay shale ( $\mathrm{r}$ $=0.96 \mathrm{P}<0.05$ ) while in false bedded sandstone, it had no significant. Similar result had been reported by [9] [17][20] on the relationship between $\mathrm{pH}$ and available $\mathrm{P}$. The significant relationship between $\mathrm{P}$ and soil $\mathrm{pH}$ is an asset in soil management as status of soil $\mathrm{pH}$ can be used to predict $\mathrm{P}$-availability and unavailability for crops. This is critical since $\mathrm{P}$ - anions react quickly with some cations such as Al, $\mathrm{Fe}$ and $\mathrm{Ca}$ to become less soluble even with slight $\mathrm{pH}$ change. Organic matter had a non significant negative relationship with available $\mathrm{P}$ in false bedded sandstone $(\mathrm{r}=-$ $0.45 \mathrm{P}<0.05)$ while in Imo clay, shale it had non significant positive relationship $(\mathrm{r}=0.73)$. [20] reported a non significant relationship between organic matter and available $\mathrm{P}$ in an upperslope and midslope of a river slope in southeastern Nigeria.

Table.3: Relationship among selected properties of soils in the study area $(n=5)$

\begin{tabular}{lll}
\hline Site & Soil property & $\mathrm{r}$ \\
\hline $\begin{array}{l}\text { Mbiakpa Ibakesi (False bedded } \\
\text { sandstone) }\end{array}$ & Soil pH Vs OM & $0.64^{\mathrm{NS}}$ \\
\hline
\end{tabular}




$\begin{array}{llc} & \text { Soil pH Vs Av P } & -0.45^{\mathrm{NS}} \\ & \text { O.M Vs Av P } & -0.45^{\mathrm{NS}} \\ \text { OM Vs clay } & 0.98^{* *} \\ \text { Amuro (Imo clay shale) } & 0.06^{\mathrm{NS}} \\ & \text { Soil pH Vs OM } & 0.96^{* *} \\ \text { Soil pH Vs Av P } & -0.73^{\mathrm{NS}} \\ \text { O.M Vs Av P } & 0.99^{* *} \\ \text { OM Vs clay } & \end{array}$

\section{CONCLUSION}

From the results, five diagnostic horizons in soil taxonomy were recognized and defined on the basis of clay movement and illuviation, horizon thickness, organic matter content and presence of anthropogenic activities. Soil physicochemical properties varied in many respect. However, large scale studies may be necessary in future investigation for increased accuracy of prediction. In addition, more attributes of soil resources should be investigated to create greater confidence.

\section{REFERENCES}

[1] Abua, M.A., R.A. Offiong, A.I. Iwara and U.W. Ibor 2010. Impact of newly constructed roads on adjoining soil properties in Tinapa resort, southeastern Nigeria. Annals of Humanities and Development Studies. 1(1): $176-184$

[2] Ahukaemere, C.M., B.N. Ndukwu, and L.C. Agim 2012. Soil Quality Soil Degradation as influenced by Agricultural Land Use Types in the Humid Environment. International Journal of Soil, Forest and Erosion 2(4): 175 - 179.

[3] Ahukaemere, C.M., E.U. Onweremadu., B.N Ndukwu and U.N. Nkwopara. 2016. Properties of Soils of contrasting lithosequence in southeastern Nigeria. FUTO Journal Series 2(1): 48 - 56.

[4] Aweto, A.O. 1982. Variability of upper slope soils developed in sandstones in Southwestern Nigeria. The Niger in geographic Journal 25: 27 - 37.

[5] Bray, R.H, and L.T. Kurtz 1945. Determination of total organic and available forms of phosphorus in soils. Soil Sci. 59: $39-45$.

[6] Bremner, J.M, 1965. Total nitrogen. In C.A Black (Ed). Methods of Soil Analysis. Agron Monogr 8. American Assoc. Agronomy Madison, WI, Part 2, Pp $1149-1178$.

[7] Das, K.D., 2015. Introductory Soil Science. $4^{\text {th }}$ ed. Kalyani Publishers, New Delhi, India. 879 pp.

[8] Dick, W.A and E.G Greorich, 2004. Development and maintaining soil organic matter levels, In: managing soil quality challenges in modern Agriculture (eds
Pschjonning, S. Elmholt and B.T Christen Gen), PP 103 - 120 (ABI publishing, Wallingford.

[9] Dodor, D.E. and K. Oya, 2000. Phosphorus sorption characteristics of major soils in Okawana. Japan. Commun. Soil Sci Plant anal, 31: 277 - 288.

[10] FAO (Food and Agricultural Organization) 2006. World reference base for resources 84 world soil resources report, ISSS- AISSIBG, FAO Rome, Italy.

[11] Federal Department of Agricultural Land Resources. FDALR 1985. The reconnaissance soil survey of Imo state Nigeria (1: 250, 000) Soil Report 133 pp.

[12] Gee, G.W and J.W. Bauder .1986. Particle size analysis. In: Klute. A. (Ed.). Methods of soil analysis Part 1. Agronomy Monogr. No 9, ASA Madison, WI, Pp $91-100$.

[13] Irwark, S., A.K Surueu, . and I.H. Aydogdu, 2007. Effect of different parent materials on the mineral characteristics of soils in the Arid Region of Turkey. Pkistan Journal of Biological Sciences 10(4): 528 536.

[14] IUSS Working Group WRB 2006. World Reference Base for Soil Resources 2006. Food and Agricultural Organization, Rome: World Soil Resources Reports.

[15] Iwara, A.I., F.O. Ogundele, U.W. Ibor, V.W. Arrey, and O.E. Okongor, 2011. Effect of vegetation adjoining Tourism Facilities on Soil properties in the tourism enclave of Cross-river state. Research Journal of Applied Science, 6(4): 276 - 281.

[16] Jackson, M.I., 1962. Soil Chemical Analysis. New York Prentice Hall Inc.

[17] Khare, N.D., S. Hesterberg, G. Beauchemin, and S. Wang, 2004. Xanes determination of absorbed phosphate distribution between ferrihydrate and boemite in mixtures. Soil Sci. Soc. Am. J. 68: 460 469.

[18] Lark, M. and H.C. Wheeler. 2000. Understanding and using yield maps and analytical tool for their interpretation. Outlook on Agriculture, 29 (1): $39-45$.

[19] Mclean, E.O. 1965. Aluminium, In: C.A Black et al (Eds) Method of Soil Analysis, Part 2. $1^{\text {st }}$ ed, Amer. Soc. of Agronomy Monogr. No 9 986- 994. 
[20] Ndukwu, B.N., E.U. Onweremadu, U.N. Nkwopara, C.M. Ahukaemere. E.E. Ihem, and L.C. Agim, 2015. Variability of selected soil properties of a river slope in Amaigbo, Southeastern Nigeria. FUTO Journal Series, 1(2): $8-16$.

[21] NIMET (Nigerian Meteorological Agency), Nigeria, 2014. Climate Weather and Water Information, for sustainable development and safety.

[22] Nkwopara, U.N., E.T Eshett, E.U. Onweremadu, C.C Opara, and J.O. Omeke, 2007. Physico-chemical properties of selected soils overlying three parent materials in the humid tropics. International Journal of Agriculture and Food Systems, 1(2): 159-164.

[23] Odunze., A.C., 2003. Northern Guinea Savana soils and rainfall properties for erosion control and fertility improvement. Journal of African soils/ African union (AU). Scientific Technical and Research Commission Lagos, 33: 73-82.

[24] Ogban, P.I and I.O. Ekerette, 2001. Physical and chemical properties of the coastal plain sands soils of South-Eastern Nigeria. Nigerian Journal of Soil and Environmental Research, 2: 6 -14.

[25] Ogukunle, A.O. 1993. Variation of some soil properties along two toposequence on quartile schist and banded gneiss in Southern Nigeria. Geoderma 30(4): $397-402$.

[26] Onweremadu, E.U., F.O.R. Akamigbo, and C.A. Igwe, 2007. Lithosequential variability and relationship between erodibility and sodium concentration in soils of a rainforest. Research Journal of Forestry, 1(2): 7379.

[27] Soil Survey Staff 2003. Keys to Soil Taxonomy $9^{\text {th }}$ ed. United state Department of Agriculture.

[28] Soil Survey Staff 2006. Keys to Soil Taxonomy $10^{\text {th }}$ ed. United state Department of Agriculture, Natural Resources Conservation Service. Washington D.C USA.

[29] Walkley, A and I.A. Black, 1934. An examination of Degtjareff Method for determining Soil organic matter and the proposed Modification of the chromic and titration method. Soil Sci. 37: 29 - 37. 